products of such technical excellence as lace fabrics without a background of continual inquiry and trial. None the less, it is questionable whether inquiries into the use and handling of difforent yarns have in general been prosecuted with sufficient system to yield their full potential value. Investigations are frequently short-term projects to solve specific production problems, and are shelved when these have been overcome sufficiently for the immediate needs.

Valuable services have indeed been rendered to many firms by the Textile Testing Department, until very recently a part of University College, Nottingham, and by several research associations, but the 'working party' suggests that there are at least four factors restricting the development of research in the industry as a whole. As in the cotton industry, there has been lack of contact between the machine-holders and the machine-builders; the industry is almost entirely lacking in scientifically trained personnel in its higher ranks; the intense individualism of the industry has prevented a united approach to technical and other mutual improvements; and lastly, many machine-holders have taken a narrow view of their functions - to regard their function as limited to processing yarn supplied to them in a finished state with machinery planned and built by others, and to consider in consequence that little or no investigation is required of them other than innovations in design and yarn utilization, and handling.

These factors have to some extent been weakened by experience gained in co-operative research and production during the War, and the formation in January 1944 of a Technical and Research Committee of the Federation of Lace and Embroidery Employers' Associations led in June 1945 to the formation of a Lace Research Council, consisting of the members of the former Committee and the professors of botany (industrial mycology), chemistry, electrical engineering, physies and textiles of the University College of Nottingham. The Federation, however, was not disposed at that stage to establish a research association under the Department of Scientific and Industrial Research, but having guaranteed an income of $£ 2,000$ per annum for a period of three years, the Federation approached the latter Department to obtain Government assistance. As a result of this approach, the Research Council will have at its disposal a total income of $£ 4,500$ per annum during the three-year period and has already appointed as liaison officer in research matters a chemist of long experience of textile processes. The Council has, however, no laboratories and the duties of this solitary scientific officer are in the first place confined to formulating the problems and conditions facing the industry, maintaining contact with research associations and inaugurating investigations under contract at universities, technical colleges and elsewhere, and to the dissemination of information.

That, broadly, is the position which the 'working party' -whose conception and differentiation of research is in line with those detailed in the report of the Cotton Working Party-seeks to meet by what has now come to be the customary prescription of 'working parties', namely, a compulsory levy. It does not, indeed, suggest that a compulsory levy should be made solely for scientific and technical research : it is also intended to cover the financing of economic arid market research, the promotion of overseas sales and the establishment of a design and fashion centre. The 'working party' does not go further than to suggest that the question whether the industry can afford not to inaugurate a fully fledged research association with its own staff, laboratory and workshop should be under constant review. It does not appear, however, to have contemplated any alternative to the usual research association for an industry in which much educational work is imperative before support can be won for research, and utilization of the results of research ensured.

\section{COLOUR PHENOMENA IN THE PERCEPTION OF FINE DETAIL}

TN a recent memoir, "The Visual Perception of Fine Detail", Prof. H. Hartridge has discussed the way in which "the image formed on the retina is clarified and improved before it reaches the higher centres of the brain", and considers in particular the reason why objects in white light are not seen surrounded by the coloured fringes which are certainly produced by the aberrations of the dioptric system of the eye (Phil. Trans. Roy. Soc., B, 232, 519; 1947). To throw light on this question, observations were made of the changes in apparent colour of coloured test objects, in some cases monochromatic stimuli, when their angular size was greatly reduced and when other factors-the brightness of the background, the proximity of other coloured objects, the pupil size, etc.--were modified.

While some of the results will be familiar to readers of Helmholtz ("Physiologische Optik", 2, 128 and 239-41, 3rd Edit.), many new observations are reported, and it is shown how they fit in with the apparent absence of fringes in ordinary vision. After skittling down a number of alternative hypotheses, Prof. Hartridge puts forward his own explanation of the changes in apparent colour. His 'neurological hypothesis' postulates four nervous mechanisms (antichromatic responses) which operate locally in all parts of the fovea and parafovea and the function of which is to control the connexion between photoreceptors and cranial centres. Thus the connexion between medium-wave receptors and the cranial centre for short waves is controlled by the "yellow" mechanism, that between short-wave receptors and their cranial centre by the 'blue' mechanism. The mechanisms may also act together: the 'red' and 'green' mechanisms acting together change colourless vision to reduced (so-called diochromatic) vision, and 'yellow' and 'blue' mechanisms acting together then alter the latter to full colour vision. The neurological hypothesis is not a simple one, and without the answers to several questions, which Prof. Hartridge does not provide, it is difficult to form even a crude picture of the way the mechanisms work. It is not clear, for example, whether they have end-organs of their own or whether they must receive nervous stimuli from the photo-receptors which they are connecting or disconnecting with the cranial centres. More specific assumptions would seem necessary if any quantitative development of the hypothesis is to be possible.

To answer another main question, namely, the reason why at high intensities visual acuity depends so little on the colour of the light, Prof. Hartridge suggests that retinal receptors of each particular type (spectral response) tend to be collected in small clusters. Thus to see fine detail in blue light, the retinal image is brought on to a cluster of 'blue' 
receptors ; but if red light is used, there is a slight change of fixation to bring a cluster of 'red' receptors into action. Several experiments were made showing that slight changes in the direction of fixation for lights of different colours do occur. These changes in fixation, together with the changes observed in the apparent colour of very small test stimuli, are also regarded by Prof. Hartridge as strong evidence for the existence in the human retina of some seven types of receptor with narrow spectral sensitivity curves analogous to the modulator curves obtained in Granit's electrophysiological studies on animals (polychromatic theory of human vision).

One difficulty with this paper is that Prof. Hartridge has not only lost faith in the trichromatic theory, but he has also, it seems, abandoned the whole mode of approach through colour-matching measurements by which the purely empirical structure of the theory has been built up. One feels that the new ideas, if valid, must interlock with this empirical structure; but Prof. Hartridge does not show that they do.

W. S. Stiles

\section{FRUIT AND VEGETABLE CULTURE}

THE annual report for 1945 of the Agricultural and Horticultural Research Station at Long Ashton, Bristol, gives results of the Station's work on the scientific horticulture of fruit and vegetable crops and on their products.

Classification of the visual symptoms of mineral deficiencies of crop plants is continued by E. J. Hewitt. He uses various refinements in technique, including a 'Permutit' demineralization method of purifying rain-water for studies of iron deficiency, and a method for transplanting adult plants without root disturbance. The present survey embraces deficiencies of twenty-nine crops grown in sand culture, and one incidental result is that a high nitrogen-level accentuates the symptom expressive of boron deficiency. Some of the effects of soil acidity on crops are not yet fully understood, and Hewitt also has a progress report on this matter. It would seem that some at least of the symptoms of acid damage are those of manganese toxicity, and other interesting tentative conclusions are mentioned. D. J. D. Nicholas has investigated the validity of rapid chemical tests for the diagnosis of mineral deficiencies in potato plants. He finds a welcome accord with the results of the full chemical analysis, and with the visual symptoms. Several useful correlations between deficiencies and toxicities are established. Spraying the foliage of tomato crops with 2 per cent magnesium sulphate solution is found to be a much better control of magnesium deficiency than soil applications of the same substance, according to D. J. D. Nicholas, J. O. Jones and T. Wallace. The director of the Station, Prof. T. Wallace, with E. Catlow, gives two extensive reports on the manuring of potatoes and garden beet respectively.

A useful classification of power-operated hydraulic spraying machinery for fruit crops has been prepared by $H$. G. H. Kearns. He gives broad specifications for the chief components of spray outfits, and estimates the biological requirements of spraying. Growers should find this paper a useful practical guide to the choice of this section of equipment. The advent of D.D.T. and benzene hexachloride makes it necessary to find the best methods of incorporating these sprays in a comprehensive programme. H. G. H.
Kearns, R. W. Marsh and H. Martin have made experiments on this problem, which rather suggest that D.D.T. is an excellent insecticide against certain pests, but offers no widespread panacea of control. It was effective against leaf-curling aphids. Comparisons of three fungicides-tetramethylthiuram, ferric dimethyldithio-carbamate, and copper sebacate -were also included. The last-mentioned was approximately equal to lime sulphur as a fungicide. Other papers in this section deal with the flight period of the codling moth in relation to time of spraying $(\mathrm{S} . \mathrm{H}$. Bennett), the effect of early lifting and other factors on storage losses of onions (H. E. Croxall), attack of lettuce by two strains of the fungus Bremia lactuca, and the relation of the disease to wild species of Lactuca (L. Ogilvie), and clover-rot investigations by Moira Munro and L. Ogilvie. The general features of eelworm attacks of vegetable crops are reviewed by $\mathbf{H}$. W. Miles and Mary Miles, and A. J. Lloyd briefly outlines results of a biological method of estimating the intensity of clover stem eelworm infections in field soils. A short paper by May $J$. Haddock shows that the 'turnip flea beetle' is not a single species, but a complex of as many as eight species. They all seem to have a wide taste for cruciferous plants; but this numerical expansion of species does not seem to offer any change in methods of control.

The Station has also investigated problems relating to fruit and vegetable products. Workers in this field will find papers on the control of blackening of boiled potatoes, factors affecting quality in potatoes and tomatoes, the apple as a source of vitamin $\mathrm{C}$, and the Station's major cider research.

\section{APPOINTMENTS VACANT}

APPLICATIONS are invited for the following appointments on or before the dates mentioned :

LABORATORY ASSISTANT (Grade II) IN THE DEPARTMRNT OF ChEMISTRY-The Secretary, Bedford College for Women, Regent's Park, London, N.W.1 (December 29).

VRTERINARY INSPECTORS in the Ministry of Agriculture for Northern Ireland-The Secretary, Civil Service Commission, Stormont, Belfast (December 31).

AssistanT ChamsT in the Chiswick Laboratory-The Staff Officer (ER/E. 457), London Passenger Transport Board, 55 Broadway, Condon, S.W.1 (December 31).

SENIOR LECYURER, and a READER, IN AGRICULTURE, at Makerere College, East Africa-The Secretary, Inter-University Council for Higher Qucation in the Colonies, 8 Park Street, London, W.1 (December 31). QUALIFTED CHEMTSTS in the Generating Stations at Chelsea and Neasden-The Staff Officer (ER/E. 454), London Passenger Transport Board, 55 Broadway, London, S.W.1 (December 31).
BACTERIOLOGIST to take charge of a public health laboratory service in Belfast-The Establishment officer, Ministry of Health and Local Government, Stormont, Belfast (December 31). RASEARCH FELLOW to work on the problem of origin and measurement of stresses in cast metal product -The Professor of Industrial Metallurgy, The University, Edgbaston, Birmingham 15 (December 31). Demonstrator (part-time) IN THE PhaRMacologr DEPARTMGNT
The Dean, Guy's Hospital Medical School, London, S.E.1 (December 31).

31. Letroker IN ANatomy at Makerere College, East Africa-The Secretary, Inter-University Council for Higher Education in the Colonies, 8 Park Street, London, W.1 (January 1).

Colonies, 8 Park Street, London, W.1 (January 1). The Secretary, The University, Edmund Street, Birmingham (January I).

Lecturar (Grade IIc) IN Pharmagotogy--The Secretary, The University, Edmund Street, Birmingham 3 (Tanuary 8 ).

SCIENTIFIO OFFICER IN THE BLOOD TRANSFUSION LABORATORIES, Manchester-The Regional Transfusion Officer, Royal Infirmary, anchester 13 (January 10)

LEOTURER (Grade IIc) IN EIECTRICAL ENGINHERINQ-The Secretary, The University, Edmund Street, Birmingham 3 (January 10).

SGNIOR SOIENTIFIO OFFIOER OI SCIENTIFIC OFFICER (Ref. No. A.337/47), and a SFNIOR EXPERIMENTAL OFHICER Or EXPRRIMENTA OFFIOER (Ref. No. F.773/47), at the Atomic Energy Research Estab ishment, Harwell, Dldcot, Berks-The Ministry of Labour and National Service, Technical and Scientific Register, Room 669, York House, Kingsway, London, W.C.2, quoting appropriate Ref. No. (January 10).

DIRECTOR of a new Vegetable Research Station-The Chairman. Organising Committee, Vegetable Research Station, Ministry of Agriculture, Block 4, Bickenhall Mansions, Baker Street, London, W.1 (January 24). 